\title{
THE TRAITS OF CULTURAL CONTACTS BETWEEN ORTHODOX AND LUTHERAN COMMEMORATION PRACTICES AMONG INGRIAN FINNISH WOMEN
}

\author{
Taisto Kalevi Raudalainen
}

\begin{abstract}
This article discusses the commemoration practices shared by Lutheran Finnish women and representatives of different Greek Orthodox ethnic groups in central and western part of Ingria. The research is based on ethnographic data and interviews recorded by the author in Ingria, Finland and Estonia. The author focuses on three cases of commemorative behaviour, analyses each of them in detail and compares with the practices used among Orthodox believers. One of the most fascinating phenomena considered is the role of birch-tree as a memorial sign for the deceased person shared by Lutheran and Orthodox groups. The author stresses that marginal and unexpected death in particular needs to be supported by additional strategies of folk religiosity. For example, the more frequent and regular commemoration days of Orthodox liturgy offer for the Lutherans broader frames for dialogic relation across the border to the World beyond.
\end{abstract}

Keywords: commemoration practices, cultural contacts and fusion, Greek Orthodox folk religiosity, Ingrian Finnish Lutheranism, lament tradition, multiethnic environment

\section{INTRODUCTION}

The task of the present article is to discuss some cases of cultural contacts or even possible cultural fusion in the commemoration customs among the Finnish Lutheran women in Central Ingria. The article is based on ethnographic fieldwork and life experience interviews collected by the author during the years 1997-2002. Therefore I will focus here on commemoration rituals and practices mainly concerning contemporary Ingria. As a comparison, I will share some cases of commemoration practices among Orthodox Votians and Izhorians obtained by the research group of the Estonian Literary Museum in 1998-2003. I am fully aware that we are dealing here with a large and many-angled problem, which should 
not be attended with one solution. Here I will talk about the contacts, while in some cases it should be possible to suppose even the influences of the assimilation processes and the impact of substratum population. As different localities of Ingria are culturally quite heterogeneous, I prefer to make case analyses and try to avoid too broad generalisations.

Like almost every third Finnish folklorist, Lauri Honko had a close relation with the Ingrian material. Dealing with the prospects of the future Ingrian studies in one of his latest remarks on the topic, he pointed out that there had not been too much research on the cultural contacts in the region. L. Honko himself reported on a particular custom in the villages of Ingrian Lutherans to hang icons into a corner of their homes giving their Orthodox guests a chance to make the sign of cross upon entering the house (1990: 119-120). ${ }^{1}$ As a matter of fact, quite many common features appear in popular magic, traditional omens, healing practices, prophetic speech, and finally in the customs related to Easter, St. George Day and Michaelmas, shared by both Lutheran and Orthodox inhabitants of the region. Local Lutheran Finns in most cases tend to point out the main differences between them and Orthodox believers, and therefore people usually did not cross cultural and confessional borders. On the other hand, these borders are obviously crossed by persons with marginal cultural and confessional status for whom the fusions and convergence are part of everyday reality (see, for example, Raudalainen 2003; Raudalainen 2004).

Along the same lines, it is supposed that the laments and lamentlike invocations performed during commemoration rituals among local Finnish Lutherans in Tyrö, Hevaa and Narvusi ${ }^{2}$ parishes are Orthodox by their origin (Honko 1978: 83-84). Aili Nenola has published recently a fundamental textual corpus of Ingrian laments (Nenola 2002). It is well known that a number of wedding laments have been collected from the Lutheran Finns mainly in the parish of Tyrö, and sporadically in those of Hevaa and Narvusi (cf. Nenola 2002: 15, 37; also Konkka 1985: 13; Honko 1990: 121). A. Nenola has supposed that the lamenting tradition of Ingrian Finnish äyrämöiset-subgroup is not genuine but a borrowing from Orthodox Izhorians (Nenola 2002: 15). In addition, Ingrian Lutherans knew laments to be performed to recruits in some regions. The cultural 
contacts or possibly even cultural fusion as well as ethnic assimilation of the population of Orthodox, Lutheran and possibly of former Orthodox origin $^{3}$ had taken place.

Observing the lament-like performances of one of my informants, an Ingrian-Finnish Lutheran Maria I., during her commemoration rituals, I am inclined to find traces of the Orthodox cultural models (for example, the usage of some stereotypes and elements of recitation within the lamenting code). Additionally, dialogues with the departed ones and blessing formulas on a family burial site are quite unusual in the Lutheran surroundings. As a matter of fact, we possibly can talk about quite strong Orthodox cultural influences among the local Lutheran groups even at two levels - at the linguistic as well as the ritualistic one. Here I will focus on the latter.

Also, I will consider some differences between the Lutheran and Orthodox concept about the soul's fate after departing this world. The Lutheran church, as well as the Orthodox one, emphasizes the benefit of a burial place being located near the parochial church where ordinary services, prayers (intercessions) and sermons are permanently practiced and thus the Eternal Life, Grace and Glory are especially close to the departed ones. However, smaller burial places farther from central churchyards were much more practical and also more appreciated, especially among the Orthodox people to whom regular and numerous commemoration days are an important part of their religious life. The threshold dividing the departed ones and their living family is - to make use of a metaphor lower within the Orthodox tradition. The elderly Ingrian women frequently used to underline that visiting kalmot 'graveyard' brings some additional virtue. For them, the institution of commemoration is a reality and the feast for the departed ones is called jälkimuistot 'funeral repast', a borrowing from the Russian term pominki. Also commemorating days three, nine and 40 days thereafter were sometimes mentioned, which are obviously influenced by the surrounding Orthodox environment. Notable importance was laid, of course, on aastajam päivät 'the annual commemoration feast' (the Russian godovschina). Radunitsa 'commemoration day a week after Eastern' and troitsa 'Whitsuntide', the main annual commemoration feasts among Orthodox believers, could be mentioned by the Lutherans in Ingria as well. 
The commemoration practice is not the only feature connecting the Ingrian Finnish Lutherans' local mentalities partly to the Orthodox cultural realm. Without any doubt, one of the reasons for the fusion of the two confessional mentalities was the social practice of adopting children from the orphanages of St. Petersburg. As a rule, these persons remained Orthodox and visited the liturgies of the Orthodox Church throughout their life, but having been grown up in Lutheran homes they were frequently active members of their local Lutheran parishes. I have met some women who, mostly participating in Lutheran services, also visited Orthodox churches and wrote regularly intercessions in diptych books or simply spiski 'lists' (Russ.) according to the common Orthodox commemoration practice. The keeping of those lists is closely connected to the Orthodox liturgy. The priest reads the names of the persons, whose souls the relatives want to be included in the commemoration service both at the graveyard and at home (cf., Järvinen \& Timonen 1992: 57; see also Järvinen 2004).

In addition, turning oneself towards icons and kissing them is quite usual for these women. Honouring the icons of various Saints, Virgin Mary or Christ the Saviour, is also the reason why Orthodox people use to visualise (almost experience physically) the presence of their dead relatives. All but physical closeness - touching, stroking and kissing the departed ones before the burying of the body that can be regarded as the main characteristics of the Orthodox burial customs, are often present in the ritual behaviour of Lutherans of Central Ingria. Both in the Karelian and Ingrian female culture, the deceased members of the clan are present in ritual events and in everyday environment in a very concrete way (cf. Järvinen \& Timonen 1992: 55-56; Konkka 1985: 67-72 on the dialogical relation with the departed one during the funeral and thereafter).

I shall mainly analyse the commemoration practices of two Ingrian Finnish informants from the parish of Spankkova - Maria I., born in Korpisalo ${ }^{4}$ village in 1910, and Katri R., born in Vanha-Holopitsa village in 1911 . Both of them are Lutherans by their confession, and their cultural behaviour obviously contains some Orthodox features. During the last 40-50 years, the former lived in a sovkhoz 
'state farmstead' in Estonia, while the latter, having lived in Estonia for almost ten years, returned to her native land. Both of them have had since their early age a deep relation with their grandmothers, who taught and adapted them to the village Christianity, the traditional agrarian way of life and the corresponding worldview. Both of them had also had an extremely hard life including the loss of their homes and native surroundings, many experiences with death and social collapses since the earliest childhood, as well as complex relationships with their husbands. But they both have astonishing memory to which the multifarious traditional ethnocultural strategies (with their own specific accents) have applied in a fluid and intense way. I myself have worked with them for almost 10 years; we have met each other dozens of times and a remarkably exhaustive material has been recorded as a result. I have tried to document the major part of our conversations and the ritual (or semi-ritual) activities on video-tape during the last three years. ${ }^{5}$

\section{THREE EXAMPLES OF COMMEMORATION PRACTICES IN THE CULTURAL BEHAVIOUR OF THE INGRIAN FINNISH WOMEN}

\section{Example 1}

A spontaneous commemoration of the departed son and other family members (parents, brothers and husband) took place in Maria I.'s living room on a Sunday afternoon in spring 2002. The ritual practices focused on the improvised homealtar and photographs of close relatives on the wall of the informant's living room. The commemoration event itself was almost wordless, except for some fragmentary blessing formulae. For Maria, an eye-contact with the blessed ones through photographs was perhaps the most important aspect of the ritual.

The informant kissed her son's photo, which had been put under the framed picture of Christ the Saviour. Thereafter she made the sign of cross towards the icon and finally put her hand on the mouth (see Photos 1-3). The physical contacts, signs of cross towards the icon, kissing or putting the hand on her mouth at first and then on 

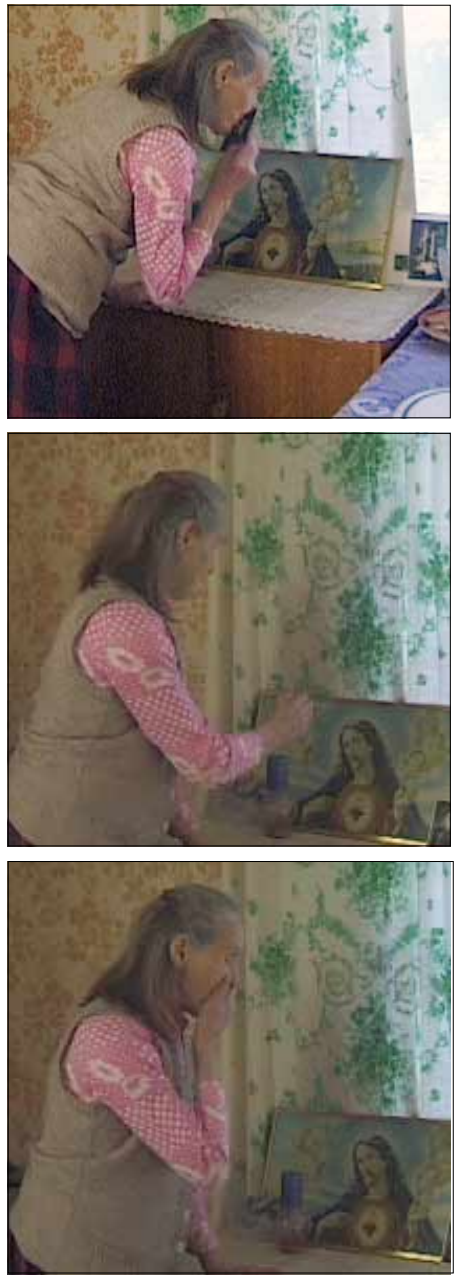

Photos 1-3. Maria I. blessing her son in front of the icon of Christ the Saviour:

(1) Kissing the photo of her son who had passed away a year before.

(2-3) Blessing him in the name of Christ, putting her hand close to the mouth thereafter. the forehead remind us analogous activities of the Orthodox believers in corresponding situations. Drinking of tea, a little meal and a symbolic drinking of vodka followed thereafter. In the end, she told me personal experience stories related to her family.

Immediately after having blessed the photo of her son, Maria turned towards the photographs of her mother, father and brothers, repeating the same practices. Additionally, after the kissing, she put her hand on the forehead (see Photos 4-6). This sequence too, reminds very closely the making of the signs of cross in front of the icons typical to the Orthodox believers.

It is important to discuss in more detail the set of photographs depicting the persons who were the objects of commemoration (see Photo 7). On the photograph below on the left was Maria (Maikko) in her home village some 60 years ago. Above on the left was Maria's mother Sofia who was brought from the village of Mosinanmylly in Venjoki parish and buried in a parochial graveyard near Maria's present-day home in Tartumaa.

The photograph above on the centre depicted Maria's "little brother" Pietari (Pekko) who died bezvesti 'without honour' (Russ.) on the Narva river during the Second World War in 1944, when Ingrian Finns (as members of a "working battalion") were 
constructing a bridge under a heavy German bombardment. Above on the right was Maria's brother Mikkeli (Mikko) who died in 1943 "without honour" in Chelyabinsk (South of the Urals) where Ingrian Finns were used to establish military industrial complexes (tank factories). A big portion of them died in inhuman conditions of working camps and "were buried" in old mining shafts. Thus, neither of her brothers was buried in the "blessed land" and the information about their fate reached the family members several decades after their actual death. Oh, where could the bones of my sons lie? - this was a frequent lament-like question of Maria's mother until the very end of her life.

Below on the right was Maria's husband Kostia who participated in the so-called "Finnish War" in Karelian Isthmus in 1939-1940. Kostia was wounded and sent "with honour" to the South of Siberia on the other side of the Ural mountains. The couple lived separately for more than 20 years because the husband could not find his family for a long time after the war was over. Maria, thus, brought up all her children alone. The photograph below in the middle represents the family of her sister Amalia, who returned after the exile in Aunus Karelia to homeland in the middle of the 1960s and died near St. Petersburg in 1978.
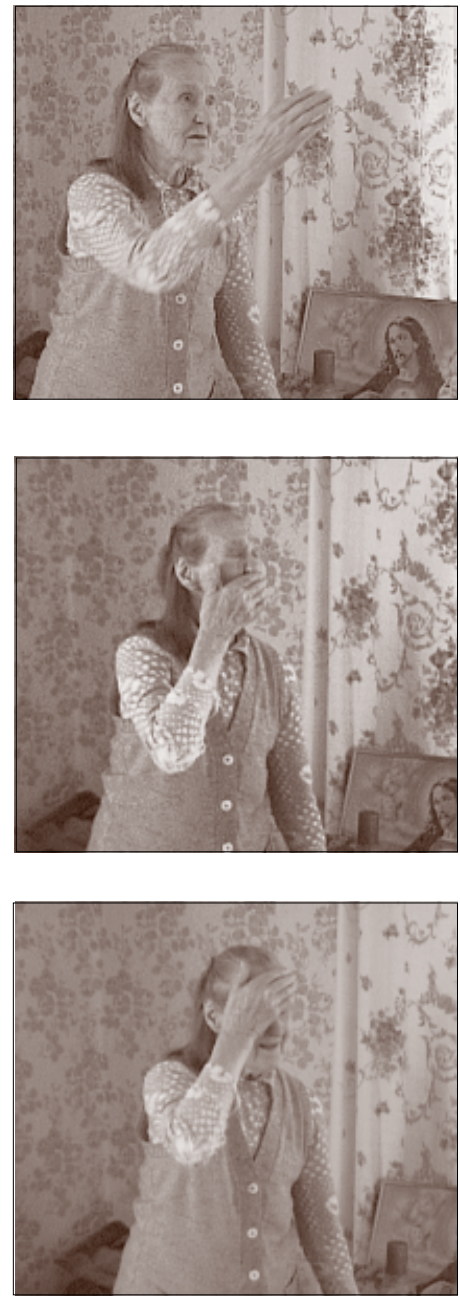

Photos 4-6. Maria I. blessing the pictures of her family on the wall: (4) Making the sign of the cross.

(5) Putting her hand close to the mouth.

(6) Putting her hand on the forehead. 


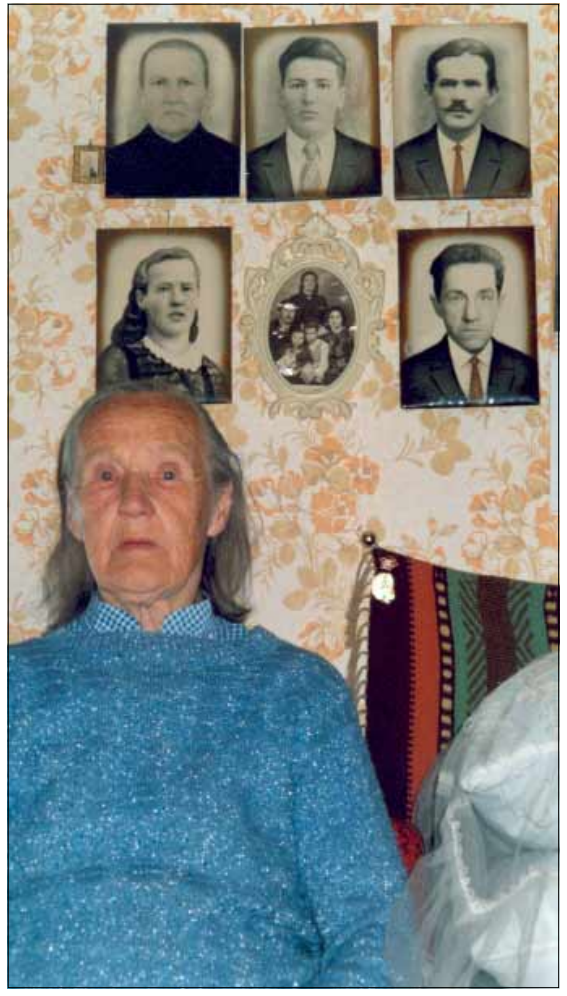

Photo 7. The photographs of the persons who were the objects of commemoration on the wall of Maria I.'s living room.
Maria used to call the whole extended family watching her from the photographs Hanikkalan suku or hanikkoiset according to the farmstead name deriving from the proper name of its former owners. ${ }^{6}$ She was always especially proud when speaking about her father's homestead and their extended family: "I'm Maikko of Hanikkala! I'm Hanikkoisii!" Leaving the earthly kin everybody wants to be welcomed by the kin of tuonela, the World beyond, according to the popular Lutheran religious understanding. The only guarantee to that was to follow the appropriate customs during funerals and to bury the departed into the blessed ground as close to the family graves in parish graveyard as possible. The following narration concerns the hope of the narrator to be buried in the family burial ground:

My sister has been buried beside my father in the Spankkuva graveyard. My uncle, granny, grandpa - all of them are buried under their earthly remains. And then my elderly brothers, who died before I was born. [---] My sister always said: "I want to be buried beside my father and grandparents." And also my mother said: "Oh, my goodness, my last will is to be buried in the graveyard of Spankkuva.” 


\section{Example 2}

Several months later, in late autumn 2002, I went with my informant, Maria I., to the local cemetery situated $7 \mathrm{~km}$ east of her presentday home in Tartumaa, South Estonia. Several times before during our previous meetings, she had pointed through the window in direction of the cemetery saying that her family members were resting there. Now, at the end of September, she wanted to be in a closer contact with the departed ones.

The visit to the family burial ground was divided into five different scenes each having its own function. The whole event was emotionally charged (see Photos 8-11).

1) Maria made a sign of cross at first and greeted the departed ones while crossing the borderline of the family burial site. She was emotionally very loaded as she had not visited the cemetery for a long time. She made a three-fold sign of cross on the "shoulders" of the wooden crosses saying the blessing formulae and naming the departed ones according to their status in family: mother, son or husband.

2) Thereafter she went on and started to clean the gravestone and put the burial ground in order, in the end lighting a candle and laying down flowers.

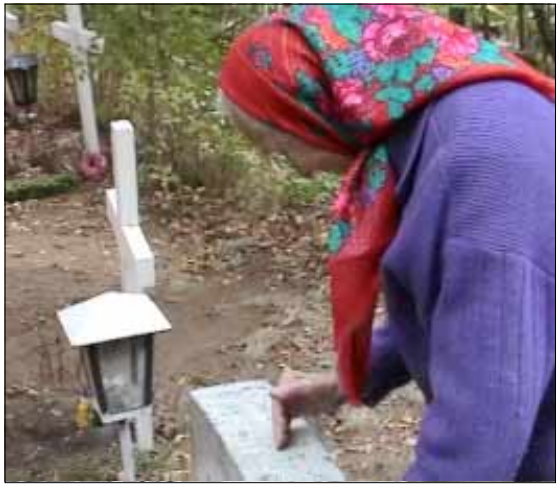

Photo 8. Making the sign of cross on the left "shoulder" of the stelos. The communication with the dead relatives begins with a blessing formula: "Be blessed in the name of Christ, Our Saviour”.

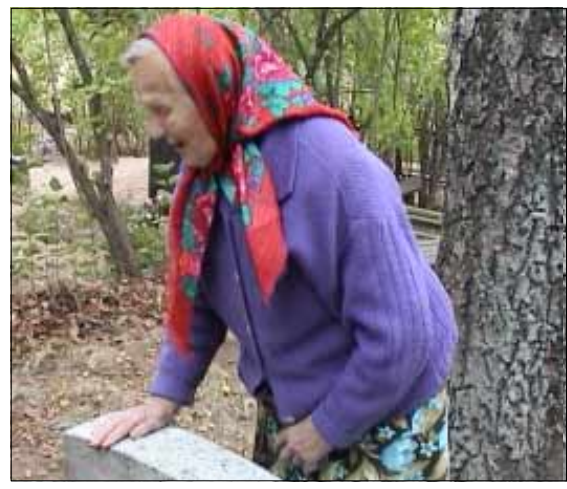

Photo 9. The 'invocation' of the dead relatives using a lament-like code: "My mother! My husband! Both of you are resting here...!" 

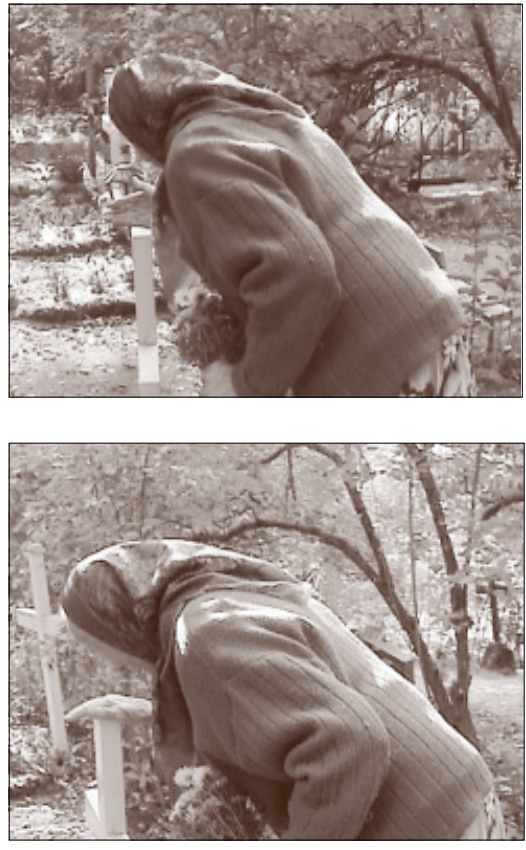

Photos 10-11. The blessing was carried out and the signs of cross on the top and the left "shoulder" of the wooden crosses were made both at arriving and leaving the burial ground.

3) And then, little by little, she started a conversation with each of the departed ones. The topics were rather intimate, although quite a lot of the themes had already reached a crystallized formulation.

4) She sang several lyrical songs of spiritual content and performed some lament-like recitations fitting the best the character and memories related to the dead persons.

5) Finally, Maria put some candies in front of the gravestone saying farewell to the departed ones and making again the signs of cross on the very border of the burial ground. She promised to visit them again, if she would be still alive, or to come beside them in eternal peace.

All in all, the visit took an hour and a half. Quite a similar structure of visiting a burial site is common among the Karelian Orthodox believers, for example, in Aunus Karelia (cf. Järvinen \& Timonen 1992: 60). And, as it was already put above, the structural similarities might be interpreted not just as accidental or typological, but most probably as the consequence of cultural fusion.

\section{Dialogue across the borders with lament-like performances and lyrical chants}

The crucial part of the ritualistic scheme "visiting family's burial ground" is, without any doubt, a dialogue and, as it is suitable for the sacred place, a semi-ritualized conversation with the departed ones. Below I will turn from describing ritual behaviour to the verbal side of this emotionally loaded event including the lament-like 
code of invocations and conversation across the border. Of course, Maria I.'s lament-like performances were not comparable to the Karelian or Izhorian lamenting tradition with its highly developed poetical system. On the other hand, their functionality and structuring role in a particular ritual event was easily observable. ${ }^{7} \mathrm{Her}$ performance was not metrically structured but contained obviously some parameters of organizing rhythm and intonation typical to the lamenting code in general. Certain crystallization on the level of lyrical metaphors in these spontaneous "lamenting breakthroughs" verifies its belonging to the genre-dynamics among Lutheran Finns in Central Ingria.

The patrilocal (and patrimonial) system in Ingria demanded that the bride be "brought in" (or "sung in") from elsewhere. Maria's mother was brought from the village of Mosinanmylly in Venjoki parish. Maria's grandmother (father's mother) Maria V. (born in the 1850s) was brought from the neighbouring parish of Kolppana. In the present context, the latterly mentioned fact is important at least from two aspects. First, Maria's grandmother was born in PieniPaaritsa, which was a half-Izhorian settlement according to the map compiled by J. Mustonen. ${ }^{8}$ Second, Maria was brought up by her grandmother. She has told me that she was a powerless premature child and the grandma said to her mother: "Oh, Sohvi, give the baby to me! I will bring up that baby!" Her grandma's feeding, nursing and socialization has been frequently mentioned in the life experience narratives performed by Maria. Therefore, it is possible that Maria's childhood socialization, early verbal experiences and her whole feminine habitus, including the use of 'lamenting code', originates from her grandmother.

Below I will present some verbal performances, different from the every-day language usage and situated in semi-ritual space of the graveyard, which testify, in my opinion, their close relationship with Orthodox practices. The ritual space itself demands from the performer much more clearly to highlight the landmarks of cultural and confessional values and personally experienced life-events. These performances thus focus in a particular way on the most important aspects of life and death.

Maria started with a lament-like performance about her own life (see Photo 12): 


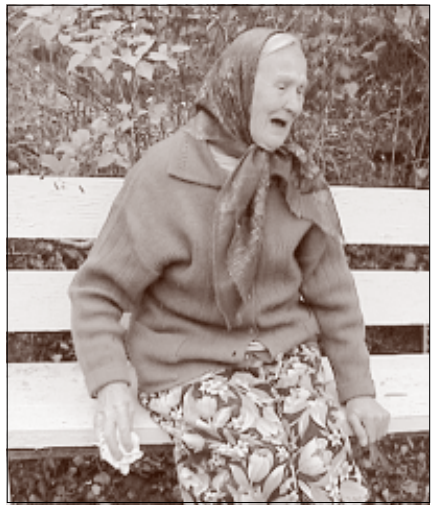

Photo 12. Maria I. performing lament-like recitatives about her own life.

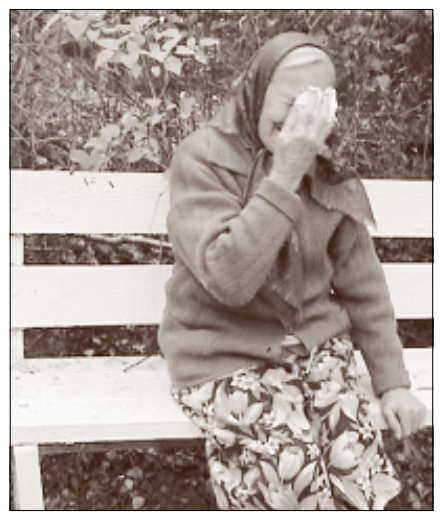

Photo 13. Maria I. performing lament-like recitative dedicated to her mother.
I have to live here still ahead.

A lot of days have been given to me, It's a pity, it wasn't my turn to go away. All the mates of mine have already gone away...

I weep all the time for my brothers, Poor me, I'm just left here alone.

I was the first to my mother-and now I am the last one.

The wealth has left me, I am quite sick, I am weak already,

I'm almost deaf, I own nothing any more,

My eyes are weak - they drop some medicals into my eyes.

They are watering heavily all the time... [Weeping]

She continued with a lament-like recitative dedicated to her mother (see Photo 13):

Mother always took care of me.

She said: "Take care of yourself, Maikko!"

And so I did.

I had to fuss and struggle hard.

I had to feed my family, Every single child of mine.

I had everything at these times.

Now I have nothing.

God the Saviour, bless her in the heaven!

Finally, Maria sang some lyrical songs, which her husband was especially fond of. Also, Lutheran hymns could be tightly connected to a particular departed person on some occasions. These personalized spiritual or lyrical chants served as verbal signs of remembrance representing predeceased family members and giving them a specific emotionally coloured place among her personal life expe- 
riences. ${ }^{9}$ This way, the emotional memories about a particular person may appear in a poetic form. Maria started the singing session reciting the first verse from a widely known lyrical song with a deep Christian content (see also Photos 14-15):

We spend our earthly life under the North Star.

However, we reach our Truly Home only behind the stars.

Then she immediately continued:

My husband's song was this one: I was happy as mummy's little child,

Now I'm sad-my heart is beating only for you.

My life and thoughts are dedicated only to you,

I cannot love anybody else in the whole world!

Oh, this was a song of the sweet daddy (husband) of mine. He always sang that way, when there were feasts. He wasn't bad, at all. But brandy corrupted him finally.

Then Maria sang a fragment of a lyrical song to her son who had departed almost a year before:

Fly, oh, fly, sweet bird, up to the clouds

Carrying my sighs to my son in the heaven!

Thereafter she repeatedly sang a lyrical song about her own life-course to her husband with whom they had lived separately for more than 20 years:
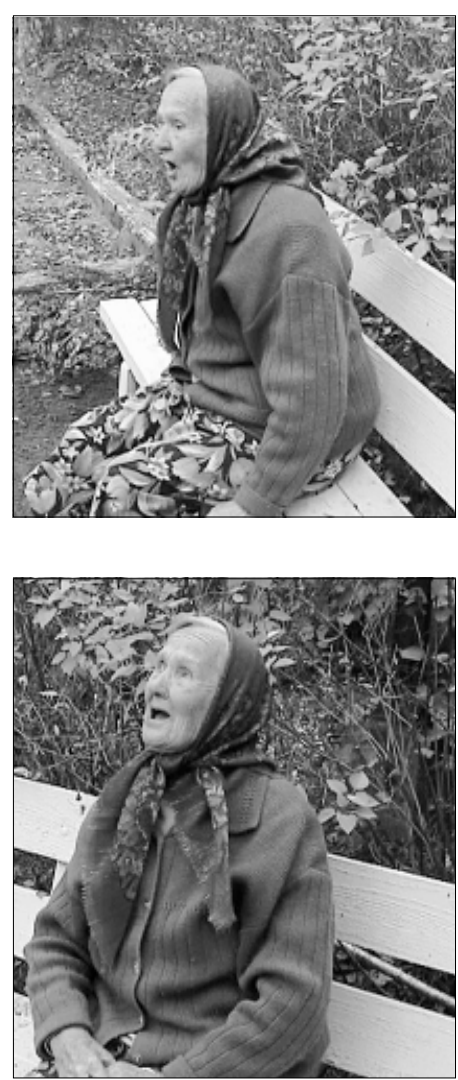

Photos 14-15. Maria I. performing lyrical chants concerning her own life-course. (14) "We spend our earthly life under the North Star..." (15) "Fly, oh, fly, sweet bird, up to the Heaven ..." 
Life would bring to me

What I didn't expect at all:

My darling had left me alone

Like a flower on the meadow

Trod down by everyone's feet.

I'm singing now

Like a bird on a branch.

Like a flower on the meadow

Over-ridden by everyone.

The echo of a warbling is in the air The tears of my sorrow flow in my eyes. [Weeping]

And, finally, she communicated directly to her husband using the lament-like code again. After the invocation, however, she spoke to him in third person taking into account my additional participation in the situation.

“Oh, hear me!" - He hears me, of course,

He certainly loved me very much. [He said] "I want to die before you, and you will stay here."

He was afraid to stay here alone, He certainly would not manage: "I want to die first and you stay alive."

And God heard him!

He took him away.

Now he rests here. [Weeping]

The performance event ended with the final comment: "Nobody knows the day when it is time to pass away."

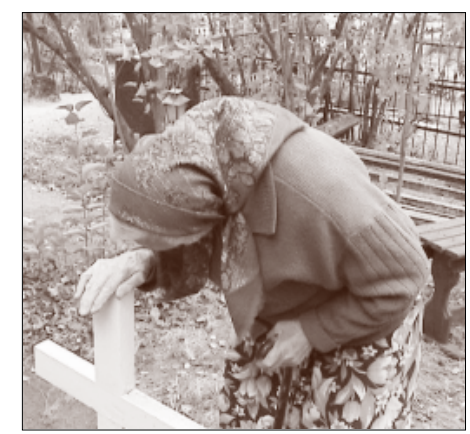

Photos 16-18. Maria I. by the wooden cross of her husband making the signs of cross and blessing him: "You were my husband and you still are my husband!" 


\section{Departing the graveyard}

After the singing we began to leave the burial site. Maria I. went to the wooden cross of her husband again and repeatedly made the signs of cross, kissed the cross, blessed the dead husband and said: "You were my husband, and you still are my husband! [Twice] Be blessed in the name of Christ in the Heaven" (see Photos 16-18).

Then, suddenly, Maria remembered that she had taken along some candies and she left them in front of her family's gravestone (see Photos 1920) following thus the custom, which is common mainly among the Orthodox believers. Maria put these in a purely Lutheran burial place like the Orthodox believers nowadays often drop caramels instead of traditional commemoration with wheat, rice or fish-pies, symbolising according to the teaching of Orthodox Church, vechnaia pamiat' 'the Eternal Life' and Resurrection after the Last Judgment.

Before we started off from the graves, Maria said the final farewells and made a three-fold sign of cross (see Photo 21):

Now, I have to leave you until the next visit - if I am still well. If I will not come, I am too tired to make it. Then it will be a time to lie down beside you. Beside you, $K$., or beside you, mother... Be

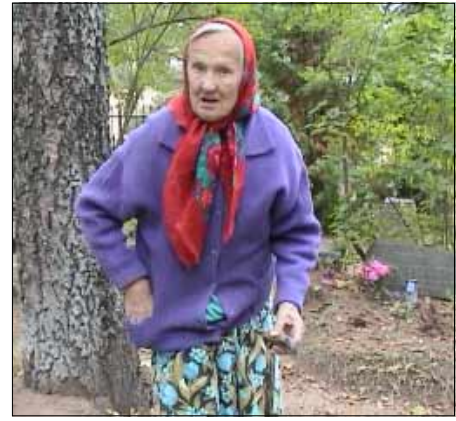

Photo 19. "I've brought some candies with me..."

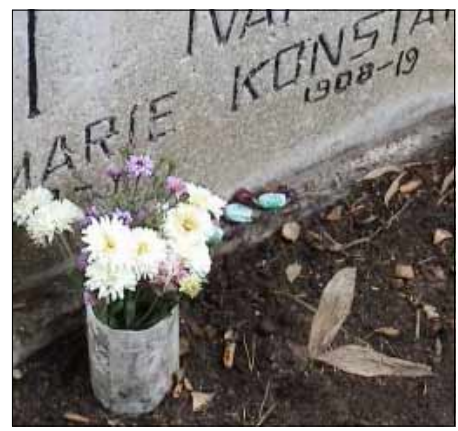

Photo 20. The candies (litentsat) in front of the gravestone.

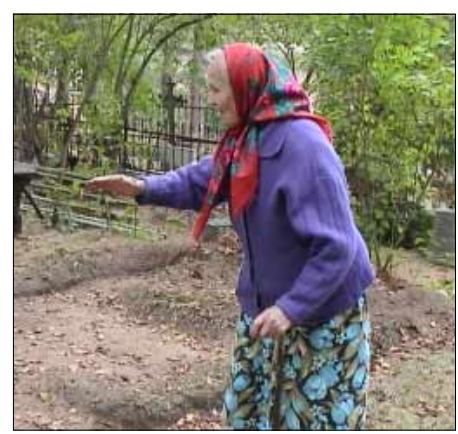

Photo 21. Maria I. saying the final farewells before turning back from the graveyard. 
blessed. Then it is my turn. This hour is not far-my age is too high already.

\section{The birch as the memorial sign}

One of the most interesting comments made by Maria I. in the very end of her visit to the burial ground concerns a rather old birchtree growing beside the graves. Maria said: "There is a nice birchtree just next to the site, which makes it easier to find the place". This detail should not be overestimated, as I have had several other experiences related to the birch-tree as "a sign for commemoration" during my field trips in Ingria. My question is whether this is once again a borrowing from the Orthodox tradition as the birch is widely known as a tree of commemoration among Orthodox Russians and Komi people in the north-east areas of Europe (see, for example, Komi Mythology 2003: 158, 254, 355). Or is it a belief originating already from the common Balto-Finnic worldview as A. Vilkuna (1989) and L. Honko (1969) have tried to show? I would not try to reach any definite answer here but rather to set up possible interpretations of the given field data.

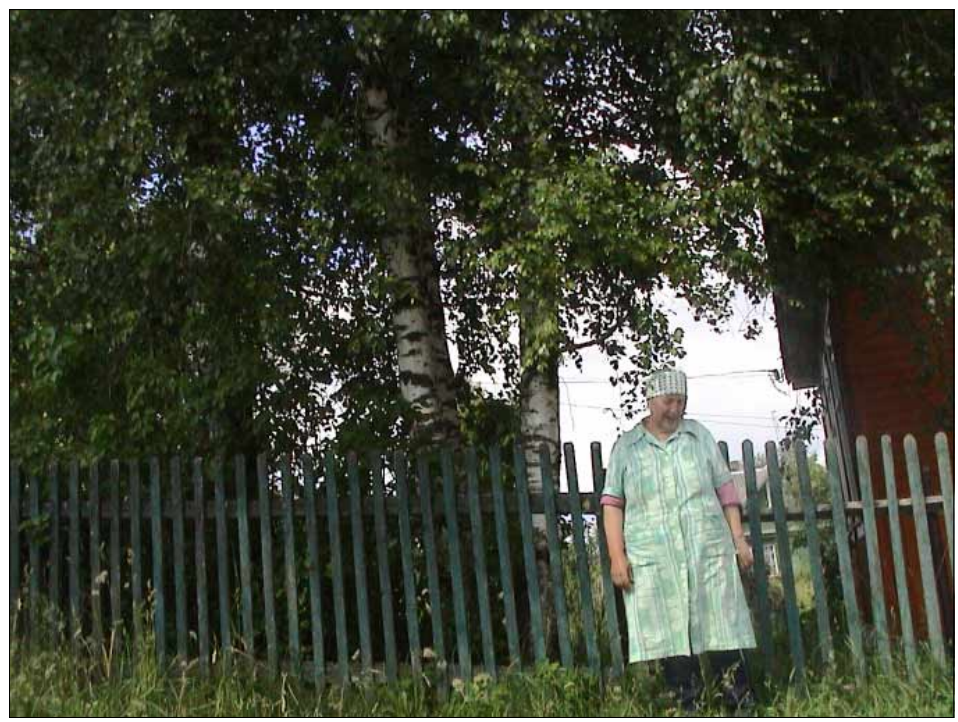

Photo 22. Amalia $K$. standing under the three-forked birch-tree, the one she called tytön koivu ('the daughter's birch'). 
Maria's short announcement might easily refer to an age-old birchtree still growing on their family burial site near the church of Spankkova in Central Ingria. She told me that her grandmother had buried her miscarried child in a big matchbox under the roots of a birch-tree on the corner of the burial ground in the $1880 \mathrm{~s}$. So, the birch has served as a "commemoration sign" in the context of burying already more than hundred years.

It was allowed to bury miscarried children in the blessed ground at the parish graveyard but the priest did not bless these graves. ${ }^{10}$ Although an action of that kind was wholly legal, nevertheless the unblessed beings acquired the status characterized as dangerous or at least ambivalent in folk tradition (cf. Pentikäinen 1968). Therefore, instead of a liturgical blessing and erecting a wooden cross, individual prayers were carried out by the women and in the particular case the birch has functioned as a memorial sign. ${ }^{11}$ Thus, planting (or choosing) the birch-tree could be seen as a kind of substitute for the cross as a sign of resurrection and reaching eternal life. Typologically similar customs planting and memorizing the birch or the fir have been documented in commemoration practices among the Komi people (see Komi Mythology 2003: 254-255, 355).

Using quite fragmentary field-data as the traits or clues, we will probably never understand entirely what true Christians were actually thinking while burying her child without any blessing. Did they expect the "innocent children" reach Paradise "directly" without obligatory priestly blessing? A miscarried child could easily be understood as already having a soul and it was simply impossible to take the final leave without any ritual marking. Did Maria I. choose the tree, marking the straightest possible contact with the dead relatives waiting already for final resurrection in the World beyond? However, there are some other cultural explanations available.

The importance of the birch-tree as the representative sign of mental boundaries appeared in several spontaneous performances of elderly women in Ingria during my field trips in 2001 and 2002. During my field trip in 2002, I spent a whole day in the village of Arponja in Kupanitsa parish interviewing Amalia K., a 75 year-old woman, a Baptist by confession, who had lost her daughter to cancer at an early age. She told me that at the age of twelve her daughter had planted a birch-tree branching later into three. It is almost 
impossible to guess whether we should see the narrative as a result of the traditional belief or did it really happen that way but the fact is that looking at the tree always made her think of her daughter. Thus, this kind of an anomalous three-forked tree could easily represent the memory of the dead person (see also Photo 21).

It is interesting to mention that an almost analogous story was told in 2000 by Anna J., a half Izhorian, half Votian 95 year-old woman in Luuditsa village of Narvusi parish. She had planted two birchtrees, together with her beloved grandson, some decades ago. The birch-tree dedicated to her grandson was broken by their neighbours' cow and dried up. Anna J. interpreted this fact as a divine omen. The boy was killed in the army some ten years later. The other tree grew up and grandma had reached almost the age of Methuselah.

Anna J., watching the tree in front of her garden, always commemorated her grandson, and while telling the story we can also witness the breakthrough into the 'lamenting code'. She recited the following words resembling to a lament:

They have terminated this kind of a youngster!

The hand of his was always in my hand,

Wherever I came, he was with me,

His hand was still in my hand.

The father cannot forget,

His hair has got gray.

You might not change the fortune,

It has to come,

Misha-Misha! [---]

I loved that boy very much,

People live in a totally new way now,

They have to fight and struggle all the time.

The wars are made to kill,

The men have been killed at their early age,

They have been taken into army and killed there. 


\section{Example 3}

I had an opportunity to visit the birthplace of one of my key informants Katri R. with herself in Vanha-Holopitsa village of Spankkova parish in 2002. Although we spent only half a day in the village, one of her aims was to see again and touch her "mother's birch-tree" in front of their former homestead. Katri's mother was buried outside of homeland, in Estonia, in the 1950s and therefore she was seeking a suitable place and sign for commemoration and linked the memories of her mother with the particular birch-tree. The other birch-tree growing in the same place was planted by her uncle (the brother of her mother) and dedicated to Katri herself to commemorate her baptism. The most remarkable aspect of this particular situation was that Katri leaned against the trunk of her "mother's birch" exactly the same way as Orthodox Ingrian women used to lean on the "shoulder" of wooden crosses. We could see from Katri's expression that her mother's figure really seemed to appear in front of her (see Photo 23).

Let me compare the performance of Katri R. with the commemoration practices of an Orthodox woman from the village of Jõgõperä of

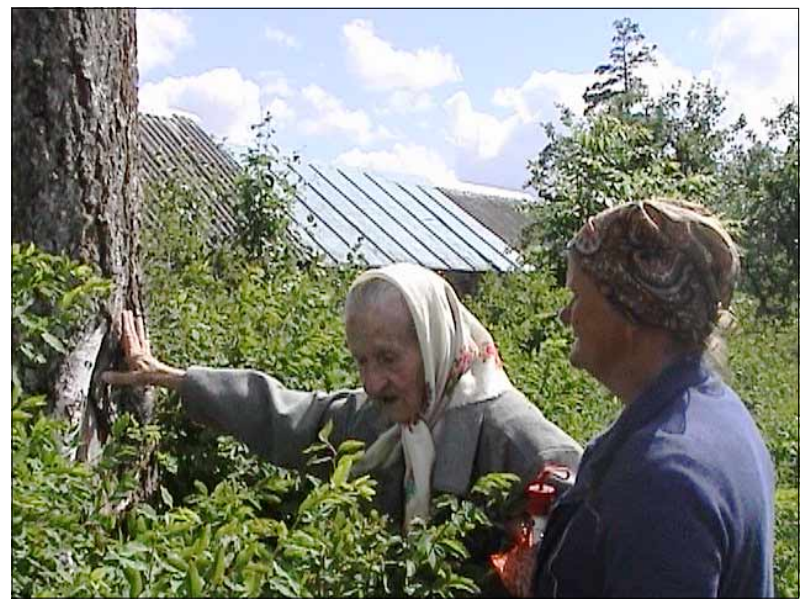

Photo 23. "This here is my mother's birch-tree..." Katri R. leaning to the treetrunk of her "mother's birch". Anni H. representing the middle generation of the post-war period is listening very carefully. 
Narvusi parish, recorded in the year 2000. The 74 year-old Votian Liolia T. leaned quite similarly on the "shoulder" of the wooden cross of her mother at the family's burial site while reciting lamenting phrases. Such gestures can be partly explained on the basis of the anthropomorphic shape of the cross-sign, which - at least in the Ortodox tradition - stands as the substitute for the "living dead" in the ritualised activities of commemoration situation. ${ }^{12}$

One should recall here the well-known karsikko-tradition that was widely spread in the east (mainly in Savo district) and north of Finland (Karelia), and sporadically also in South Estonia (the former Old-Livonian territory). ${ }^{13}$ The dedication of a tree called nimikkopuu to a newborn after baptism (name-giving) was a rather popular tradition in Finland generally, and particularly in the North Finnish Karelia. Does a sporadic appearance of this custom come in question also regarding Ingria? In spite the fact that I personally have no more data on this particular custom from Central Ingria, it is wholly expected that similar practices were also known in this region.

The Finnish custom of selecting or planting nimikkopuu enfolded the idea that the spirit of the tree was a guardian of the newborn. The living tree (or the 'soul' of the tree) had been interpreted as a kind of double-being of the person in question. ${ }^{14}$ If something happened to the tree, also the accident was expected to take place in regard of a human being - exactly the same explanation was given by Izhorian-Votian Anna J. Respectively, also domestic animals (a sheep, cow or ox) were dedicated to particular persons the same way in numerous cases (cf. Vilkuna 1989).

We can see that the borderlines between the different realms in other types of karsikko are as strong as in the funerals. The reasoning of making karsikko after the funerals, weddings and name-giving is exactly the same. J. Vilkuna writes:

The different types of karsikko organize an individual life-cycle: the karsikko of the firstlings, first-borns or novices, the karsikko of the name day (the feast day of a particular Saint), the karsikko of the bride or dead person. These are not necessarily related to each other but could be developed following a similar logic. They all are parts of the rites of passage. The different symbolic bor- 
derlines from the previous status to the next one were produced in an individual way by lopping off branches or hewing the trunk of the trees. (Vilkuna 1992: 130; cf. also ibid.: 23).

The karsikko-trees could easily become 'the commemoration signs' related to particular persons. But let us examine closer, could the cases analysed above originate in the phenomena representing the karsikko-type?

I have already noted above that in most cases in which the commemoration of a dead person was connected to a birch-tree in Spankkova and Kupanitsa parishes, the dead one had been obviously of anomalous or unnatural character: a daughter had deceased too early, a miscarried child had been buried without the blessing, the mother's grave is too far, etc. An extraordinary death always causes additional ritual behaviour in any kind of cultural environment and may accumulate rituals and beliefs belonging to the peripheral mentality related to official liturgy (cf. Loorits 1998 (1927): 42-45; Vilkuna 1992: $119-123) .{ }^{15}$ Could the exceptional status also lead to the usage of unusual and culturally strange practices? The answer might be 'yes' - if the following argumentation would be correct.

It is true that there is no clear Orthodox counterpart to the custom of karsikko because of the regular commemoration days in the popular version of Eastern Orthodoxy (cf. Vilkuna 1992: 155, 162). Even though, there is the tradition to carve Orthodox crosses with an axe into the trunks of pine-trees or spruces growing on the border of family burial grounds or graveyards in Aunus Karelia (Vilkuna 1992: 161-162; cf. Konkka 1985: the photograph section). The original idea of the carvings might be the same compared to that of $k a r s i k k o$, i.e. to end up the uncertain liminal period and to close channels between this world and the World beyond. ${ }^{16}$ Situations like these are ambivalent or reciprocal, at least. It seems to me that crucial in the Orthodox tradition, that is, in the practice of hewing the trunks, is the very idea of memorizing the so-called vechnaya pamjat' 'eternal memory', which is not related with the attempts to hinder the departed ones. ${ }^{17} \mathrm{So}$, I tend to favour the solution that the planting and commemorating the birches in Ingria is influenced rather from the side of Orthodox belief-complex and does not belong to the so-called karsikko-cult shared by the Lu- 


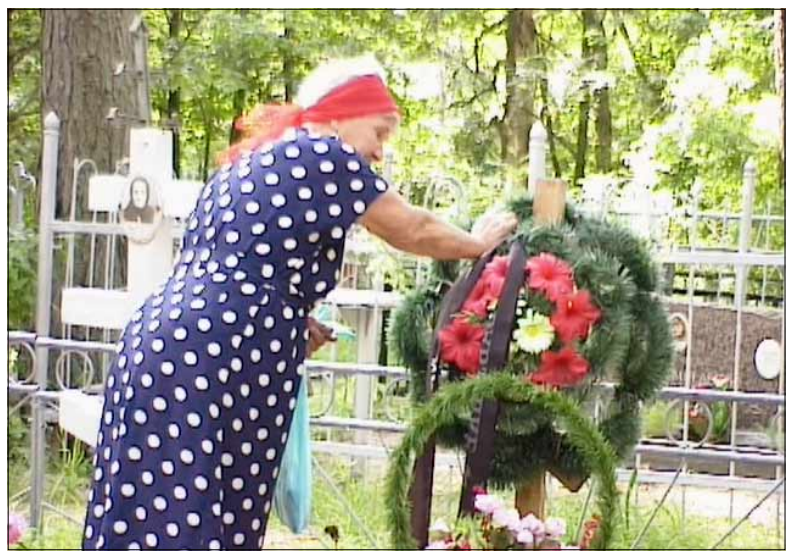

Photo 24. "All my family is here - my mother and father and sisters..." Votian Liolia T. from the village of Jõgõperä in Narvusi parish leaning on the "shoulder" of her sister's wooden cross at the family's burial place.

theran believers in Savo, North Karelia and Estonia. In addition, all the above-mentioned karsikko-types are only typologically related to each other, and they appeared as separate traditions just after the Reformation - the fact, which is convincingly affirmed by Vilkuna (1992: 156). Vilkuna's interpretation well illustrates the ways the mentalities depend on the ideologies of a particular epoch and how careful we should be while discussing the phenomena of folk tradition.

Here, in the particular cases described above, a dialogic relation was wholly expected as this is a rule among Orthodox believers. There is no clear evidence about the magical hindrance, where the tree could stand as an ambivalent sign both for abjection and/or remembrance - which is the essence of karsikko. In my opinion, in the cases analysed above, there is no attempt to tie a dead person's soul to a concrete place having thus some ritual control over it (cf. Honko 1964: 277). On the contrary, the dynamic reciprocal relationship with the departed ones alleviates the mourning excitement connected to the unusual or unnatural death. The concept of intercession and prayer for the dead persons in the World beyond, shared with the official Greek Orthodox Church, had in particular cases the influence on individual psyche during the mourning period (see, 
also Honko 1963: 114). Orthodox eschatology gives to the mourner a possibility to ask for the deceased person's well-being in the World beyond and to take care of them. Supposedly, that might be one of the reasons for taking over some Orthodox practices by the Lutheran-Finnish inhabitants in Ingria.

\section{DISCUSSION}

The Lutheran Church emphasizes the passive temporal aspect of Eschatology - when the departed one will resurrect in the Heavenly Kingdom or reach the Eternal Life at the end of times. However, Orthodox Eschatology focuses on the actively presented visual narrative about Christ's descending and crushing the gates of the World beyond (cf. Makkonen 1989), which activates the ordinary believers to influence the well-being of their relatives in the World beyond. One of the ways to communicate is to compose the spiski 'memorial lists' or to carry out the regular treatment on burial grounds in commemoration days, especially during the Easter period. Lutheran Eschatology says that the Lord's Grace will save all the departed ones and they just have to wait passively until the Last Judgment's Day in an indefinite space in-between Hell and Heaven, called tuonela in Finnish. The Lutheran annual feast calendar is more focused on Christmas time, which deals much more with the Christ's deeds in this world than in the World beyond. Because of the lack of rites of "incorporation into the new world" (van Gennep 1960: 21) in the Lutheran environment, it is possible that Lutheran believers, using ethno-cultural strategies of problem solving, could easily lean on customs available in the neighbouring Orthodox tradition (cf. Vilkuna 1992: 158-159, 129-129). Here the Lutheran believers have found the channels of dialogue across the borders put forward by the official Lutheran doctrine.

Thus, it is intriguing to point out that tuonela as the Lutheran and specifically Finnish term is conceived as a place which is rather different from the Biblical gehenna, the original concept of the hell. However, it has to be mentioned that the local features of thanathology, folk concepts about the person's existence and status after death, may be significantly different from the canonized con- 
cepts in the so-called "little traditions," weakly controlled by the official Church. ${ }^{18}$

On the contrary, the Orthodox approach maintains that the departed ones can expiate their sins and reach "the Right side" (or at least a better place) with the help of intercessions, prayers and rituals made by the living persons. Therefore, bringing offerings and lamenting are rational activities among the Orthodox believers. Using the lamentation, for example, they call the dead relatives to welcome the new members among them (cf. Konkka 1985: 10, 50-51, 82, 92). The active dialogue with the departed relatives belongs to the Orthodox commemoration code. Here the dangerous aspects related to death, including defensive strategies and a control over the correct relations to the realm of the death, are often already included in that very dialogue itself. Therefore it was rather surprising to meet similar behavioural features also among the commemoration practices of the Lutheran women.

As already O. Loorits (1998 (1927): 43) has mentioned, the Lutheran concept of the World beyond (Finnish tuonela) as an obscure place "in-between" is the source of simultaneous abjection and demonising of the departed ones. When the clear visual picture of the Purgatory was abandoned, the Lutheran approach substituted the concrete act of confession and conversion from the sins with more vague ideas (cf. Saarinen 1989). The former calendar of feasts with particular days for relating oneself to one's dead relatives was neglected too. The dead ones, on the one hand, should not appear at all, or, on the other hand, they could appear at any time (cf. also Vilkuna 1992: 157-158).

It is quite normal that there exist different strategies of commemoration behaviour in the multi-confessional environment especially in regard of marginal personalities, unusual death and conditions lacking rigorous doctrinal supervising. I would like to emphasize especially the role of the psychological needs influencing cultural behaviour here. If different behavioural strategies of commemoration practices and interpretations related to the World beyond are available, these are also used by the mourners who face the need to calm down. 
Dealing with the problem of fusion in a predominantly oral environment, I would also like to point out the tendency of a so-called 'ethnic diplomacy' salient for the multicultural territories of several confessional dominants like Ingria, Transilvania or the Balkans. The invention and attribution of contrastive ideologies characterizes cultural environments resting generally upon written texts as the guiding and controlling institutes. The oral transmission (even if related to the basic written texts) does not contain a straight demand for "the pure and genuine". Therefore a continuous "dispute" is allowed and even needed in oral culture. Here the original additions and new inventions are constantly done. Keeping the icons in the holy corners of basically Lutheran homes is an extraordinary example of ethno-methodological practices. But the same "diplomatic" activity on a grass-root level is constantly present as a discursive re-evaluation of the habitual structures in actual conjuncture (cf. Sahlins 2000: 158). ${ }^{19}$ The simplest case in this respect is, of course, to learn the most important conversational phrases, expressions and other communicative markers of the sign-systems used by the neighbouring groups. On the other hand, this also means that some of the most effective and attractive speech practices and conventions may be not "genuine", but taken over from the neighbouring groups. The borderlines between different confessions are thus constantly corrupted and re-established. Single precedents on the individual level would be legitimised through accepting them as a part of social constitution. The daily work of cultural adaptation and translation is continuously done. ${ }^{20}$

It is obvious that the Lutheran inhabitants of Central Ingrian parishes were at least partly under the influence of the Orthodox cultural practices according to which a regular dialogic communication with the departed ones was acceptable and even expected. Let me quote here some passages by N. G. Holm (the emphasises are mine - TKR):

Rites and rituals are a fairly fixed symbolic language, which people have used at all times, and which have created solidarity within groups and meaningful experiences for individuals. [---] A special rite or ritual becomes meaningful and significant for an individual when her inner experiential structures correspond to the alleged content of a certain action. (Holm 2002: 71$72)$. 
The cases of cultural fusion in commemoration practices of Ingrian Finnish women could be caused mostly by the need of solidarity in the territories where there were settlements of mixed population. On the other hand, the multitude of problem solving strategies made it possible to use simultaneous and parallel customs of different origin, because the clergy had not enough control over individual and inner-group practices. The fact that the extraordinary death also needs some additional psychological treatment could influence particular behavioural choices.

\section{Acknowledgements}

The article was written within the grant project of the Estonian Science Foundation (grant No. 4939).

\section{Comments}

${ }^{1}$ Honko uses the term 'cultural fusion', while there is also the possibility just to mention common or similar ethnocultural features shared by the ethnic groups inhabiting a particular multiethnic region (see, for example, Gadlo et al 2004: 18).

${ }^{2}$ In the article I will use Finnish-biased toponyms of Ingria (see Figure 1).

${ }^{3}$ It is well-known that the segregation policy lead by the superintendents of the Ingrian Lutheran Church, Heinrich Stahl and Johannes Gezelius (jun.), demanded from all the inhabitants speaking Balto-Finnic languages, that is, the Orthodox Votians and Izhorians, to turn into the Lutheran confession, especially during the second half of the 17th century (cf. Saloheimo 1991: 76-80). Joh. Gezelius went even so far as to declare that the Votians and Izhorians had converted into the Orthodox confession just recently before the so-called "Rupture War" in 1656-1658. Some of the reflections of this type have been the source of the marginal idea still partly alive in the Votian villages of Vaipoole area that the local villagers identify themselves as the "people of Swedish origin" (see Raudalainen $e t$ al 2004). The other reason for that kind of self nomination possibly has deep rooting in the Russian folk culture where the majority of foreigners (those who do not speak 'our language' and do not share 'our confession') were classified as "Swedes", "Lithuanians" or "Germans" according to the recent military conflicts.

However, the historical fact is that the majority of the Orthodox inhabitants had escaped into the nearby forests when the Lutheran priest came 


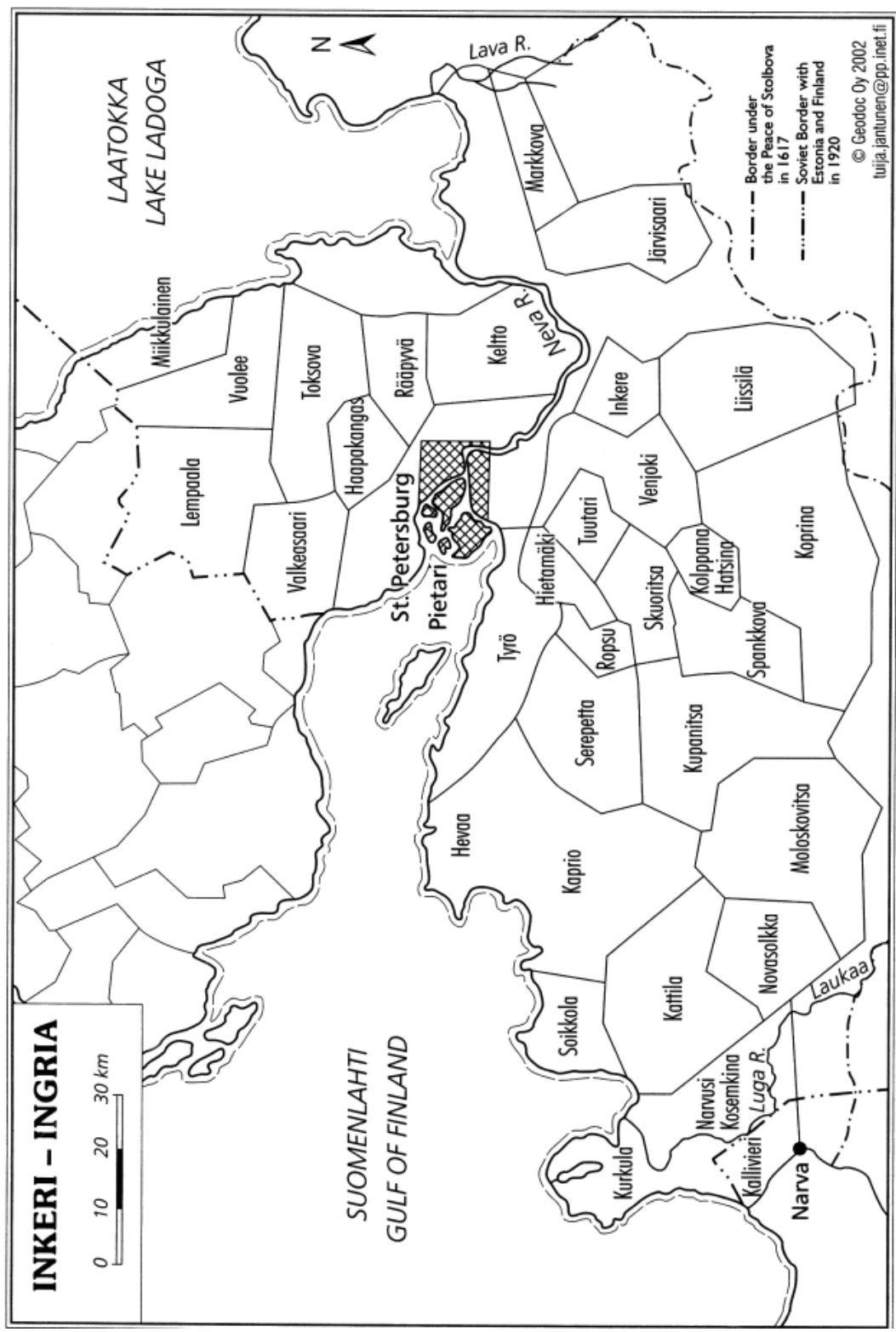

Figure 1. Map of former Lutheran parishes in Central and Western part of Ingria. (The majority of my informants came from Spankkova and Kupanitsa parishes.) Used with permission from Nenola 2002: 12. 
into the village to check their knowledge in the basic dogmas of Christianity (Väänänen 1987: 20-23). The superior mentality including an underestimation and even a kind of "stigmatization" of the local Orthodox inhabitants by Finnish Lutheran priests and even parishioners themselves has also a rather long-lasting history, having continued in some circles until the beginning of the 20th century. However, on their own side the Russian troops losing the ground during the "Rupture War" had taken with them a rather large amount of Lutheran (also Lutheranized) inhabitants of Ingria (Sihvo 1991: 346-347).

${ }^{4}$ The name probably roots in Korp-Iisaro 'the Izhorian village in the wilderness', which refers to the former Izhorian population of the area who were later Lutheranized. Y. Kriukov-Antonov, researcher of the Ingrian onomastics, has turned my attention to the fact that the village of Iisaro in Koprina parish is related to the village of Korp-Iisaro. It is possible that one part of the population migrated to the village of Korp-Iisaro from the parish of Koprina. Therefore the parallel name of the Korp-Iisaro village is Uusikylä ('the new village', Russ. Novo-Korpesalovsk). Izhorians lived in the neighbouring parish of Koprina on the upper tributaries of Oredezh River still about hundred years ago. In 1959 Estonian linguist A. Laanest tape-recorded the last representative of this linguistic subgroup in Novinka village situated between Suida and Jaschera Rivers (see Laanest 1966: 229).

${ }^{5}$ The Photos included in the article originate in the MiniDV-tapes shot in the field trips, which were made by the fieldwork team of the Estonian Literary Museum and by the author of the present article in 2000-2003.

${ }^{6}$ Obviously it is a derivation from the proper name Johannes / Juhana, which appears, for example, in family names like Hannikainen / Hänni(käi)nen.

${ }^{7}$ The particular lamenting code is also met outside the ritual space in the context of rather free narrating of "personal experience stories". There is not enough room to analyse these performance situations separately. (I will shed some more light on this kind of verbal practice in my doctoral thesis.)

Nina Lavonen (1996: 233) has also documented such prosaic lament-like performances at the funerals in Aunus Karelia in her article. The mourners have lost the close contact with the living lamenting tradition, but the general scheme of "the passing away" inevitably demands the verbal contact with the deceased. Therefore the monologues of rather free content dedicated to the deceased were performed. 
8 The total percentage of half-Izhorian villages in Spankkova parish was about $15 \%$ at the beginning of the 20 th century (cf. Sihvo \& Nevalainen 1991: 607-608). I will not focus here on the former possible assimilation processes in particular area, but quite a large number of loan-words of Izhorian origin in Ingrian Finnish dialects allow to put forward such hypothesis.

9 The function of these songs seems to be quite similar to that of, for example, Saami yoiks or some other performances connected to the personal fortune or life-course.

${ }^{10}$ The ones who commit suicide, murderers and murder victims were buried in a certain marginal part of the graveyard. Crosses were not allowed to be erected there. For example, Anni P. from Hylkysi village of Kupanitsa parish said that the place for those who had died under suspicious circumstances and sinners was located in the local parish graveyard "on the side towards Lopitsa village". These places were charged with strong demonic power (resp. väki) reflected in memorates and personal experience narratives.

While asking about practices related to the miscarried children in Seropitsa village of Kupanitsa parish in 1999, the informant Aleksandra $\mathrm{K}$. answered that these children were buried in the blessed land without priestly blessing: "There was an old Finnish-speaking woman of Orthodox confession, called Annukka, who said that there was no need to bless a miscarried child. But anyway, she blessed him. [---] She was holy person by herself. [---] They came with their own shovel and put it on the grave of any of their relatives."

${ }^{11}$ Several Ingrian women have said to me that blessing and praying, even preaching was allowed by every single Christian, being confessed, in the situations where priestly liturgy was not available. These cases included, for example, emergency baptism and blessing of the departed one, the lack of priests after severe Stalinist repressions in the 1930s, and finally the environment almost absolutely lacking the religious way of life in Siberia, Central Asia and elsewhere, established lay female priesthood among Ingrian Finns. A considerably high tendency towards the sectarian and free-church movements among the marginal ethnic groups is noticeable. I would also like to mention also the religious-historical fact that the sectarian movement called (hyppy)seuralaiset 'members of the congregation of jumpers' (Russian skakuny) earned comparatively large popularity among the Lutheran Finns in Central and Western Ingria. Supposedly, it could be one of the background phenomena shaping the basic attitudes concerning lay prophetism. According to G. Luther (2000: 86) the total number of sectarians in the parishes of Inkere, Keltto, Kupanitsa, 
Moloskovitsa, Skuoritsa, Tyrö and Venjoki was more than 2000 at the end of the 19 th century.

${ }^{12}$ The ancient idiom for the same phenomenon sounded sēma-sōma - 'the sign is the corpus'. The cross, as well as the birch-tree itself, are represented by the anthropomorphic parameters having the "feet", "corpus" (trunk), "shoulders" and "head" (cf., for example, Hoppál 1986).

${ }^{13}$ There were some sporadic karsikko-cases in Kanneljärvi (Karelian Isthmus), Lempaala, Vuole, and Tuutari parishes in Ingria - thus mainly in the area inhabited by the ethnic group of äyrämöiset in the Northern part of Ingria (cf. Vilkuna 1992: 40, 56,-57, 99, 102, 120, 138-139, 156). See also Torp-Kõivupuu 2003.

${ }^{14}$ Correspondingly, there was an idea of identifying the life of a human being with the "life cycle" of a tree in Komi beliefs (see Komi Mythology 2003: 276).

15 The planting of a tree (fir) on the grave instead of erecting the wooden cross in cases of extraordinary or accidental death (the death of unbaptized children, evil people or drowned persons) are usual also common among Komi people (see wozha pu, Komi Mythology 2003: 254-255; 355).

${ }^{16}$ Cf., for example, Jetsu 2001: 145. On more general ideas about the cognitive theory of the "sacred" see Anttonen 1995: 155-157.

${ }^{17}$ As O. Loorits (1998 (1927): 43) has noted, stories about the 'demonised dead' are extremely wellknown in the Lutheran cultural context, where the relations with the Purgatory were annulled, the personal confession was pushed to the periphery and regular reciprocal relations with the departed ones were minimized. Besides, the response to these relations was not a common enterprise of the whole community, but only the intimate "work" or "task", which every single individual had to carry out personally.

${ }^{18}$ On the differences and dynamics of local ethnic traditions, see Siikala 2000: 61-66 and Jetsu 2001: 35-39. On the differentiation between the "little" and "big" traditions, see Jetsu 2001: 32.

${ }^{19}$ See also Laitila 2002: 133-149 and Pozsony 2002: 212-214 on the ethnoconfessional and ethical values in multicultural environment.

${ }^{20}$ The code-switching and continuous active translating from one language (Russian) to another (Finnish, Karelian, Votian etc.) characterises all kinds of narrative events particularly in the territories of Ingria where Russian population made up a remarkable percentage. Although mostly men had closer contacts with the external sphere and some competence in Russian, 
women often did not speak Russian at all. It did not mean, of course, that no cultural translation was carried out. The adaptation of 'foreign' practices was done in other communities and then adapted to the native surroundings. The Central Ingrian parishes Spankkuva and Kolppana were almost 80-90 per cent Finnish in the 19th century but a significant portion of Russian inhabitants lived in the neighbouring parishes and market towns (for example, in Venjoki, Kupanitsa and Kolppana). It is evident that Lutheran Ingrian Finns communicated also with other Orthodox BaltoFinnic ethnic groups.

\section{References}

Anttonen, Veikko 1995. Ihmisen ja maan rajat: 'Pyhä' kulttuurisena kategoriana. Suomalaisen Kirjallisuuden Seuran Toimituksia, 646. Helsinki: Suomalaisen Kirjallisuuden Seura.

Gadlo, A. V. \& Verniaev, I. I. \& Egorov, S. B. \& Chistiakov, A. Y. 2004. Etnografiia Severo-Zapada Rossii. Juzhnye okrestnosti Peterburga Priladozhe - tsentral'nye raiony Pskovschiny. Sankt-Peterburg: Izdatel'stvo St.-Peterburgskogo Universiteta.

Gennep, A. van 1960. The Rites of Passage. The University of Chicago Press. London: Routledge and Keagen Paul.

Holm, Nils. G. 2002. Ritual Studies and the Integrated Role Theory. An international Festschrift to commemorate the 60th birthday of Mihály Hoppál. Ethnographica et Folkloristica Carpathica, 12.-13. E. Bartha \& V. Anttonen (Eds.). Ethnographica et Folkloristica Carpathica, 12.-13. Debrecen-Turku: University of Debrecen, pp. 63-74.

Honko, Lauri 1963. Itkuvirsirunous. Kirjoittamaton kirjallisuus. Suomen Kirjallisuus, 1. M. Kuusi (Ed.). Helsinki: Suomalaisen Kirjallisuuden Seura, pp. 82-96.

Honko, Lauri 1964. Finnische Mythologie. Wörterbuch der Mythologie. II. Hrsg. H. W. Haussig. Stuttgart.

Honko, Lauri 1978. The Ingrian Lamenter as Psychopomp. Temenos. Studies in Comparative Religion, vol. 14, pp. 79-96.

Honko, Lauri 1990. Inkerin tutkimus tienhaarassa. Inkerin teillä. P. Laaksonen \& S.-L. Mettomäki (Eds.). Kalevalaseuran vuosikirja, 6970. Helsinki: Suomalaisen Kirjallisuuden Seura, pp. 113-123.

Hoppál, Mihály 1986. Népmüvészet és etnoszemiotika. A Magyar fejfák jelvilága. Népi Kultúra. Népi Társadalom, XI-XII. Budapest: Akadémiai Kiadó, pp. 191-217.

Jetsu, Laura 2001. Kahden maailman välillä. Etnografinen tutkimus venäjänkarjalaisista hautausrituaaleista 1990-luvulla. Suomalaisen Kirjallisuuden Seuran toimituksia, 853. Helsinki: Suomalaisen Kirjallisuuden Seura. 
Järvinen, Irma-Riitta \& Timonen, Senni 1992. Memorial rituals and dreams in a Karelian village. Byzantium and the North. Acta Byzantina Fennica, vol. VI. Helsinki: Bysantin Tutkimuksen Seura, pp. 51-72.

Järvinen, Irma-Riitta 2004. Karjalan pyhät kertomukset. Tutkimus livvinkielisen alueen legendaperinteestä ja kansanuskon muutoksista. Suomalaisen Kirjallisuuden Seuran toimituksia, 962. Helsinki: Suomalaisen Kirjallisuuden Seura.

Komi Mythology. Encyclopaedia of Uralic mythologies, 1. Budapest: Akadémiai kiadó, Helsinki: Finnish Literature Society. 2003.

Konkka, Unelma 1985. Ikuinen ikävä. Karjalaiset riitti-itkut. Suomalaisen Kirjallisuuden Seuran toimituksia, 428. Helsinki: Suomalaisen Kirjallisuuden Seura.

Laanest, Arvo 1966. Isuri murdetekste. Tallinn: ENSV Teaduste Akadeemia Keele ja Kirjanduse Instituut.

Laitila, Teuvo 2002. Geography, memory and ethical values: aspects of Yugoslav history of the 1990s. An international Festschrift to commemorate the 60th birthday of Mihály Hoppál. E. Bartha \& V. Anttonen (Eds.). Ethnographica et Folkloristica Carpathica, 12.-13. Debrecen-Turku: University of Debrecen, pp. 133-149.

Lavonen, Nina 1996. Havaintoja hautajaisrituaalista Aunuksen Karjalassa. Näkökulmia karjalaiseen perinteeseen. Pekka Hakamies (Ed.). Suomi, 182. Helsinki: Suomalaisen Kirjallisuuden Seura.

Loorits, Oskar 1998 (1927). Liivi rahva usund. I-III. Eesti Keele Instituudi rahvausundi töörühma väljaanne. Tartu: Eesti Keele Instituut.

Luther, Georg 2000. Herdaminnen för Ingermanland. II. De finska och svenska församlingarna och deras prästerskap 1704-1940. Skrifter utgivna av Svenska Litteratursällskapet i Finland, 620. Helsingfors: Svenska Litteratursällskapet i Finland.

Makkonen, Risto 1989. Kuolema ortodoksisessa perinteessä. Tutkimus kuolemaan liittyvän perinteen elinvoimaisuudesta entisen Aunuksen kaupungin ja Suojärven pitäjän alueella syntyneiden ortodoksien elämässä synnyinseuduilla ja Suomessa vuosina 1930-1985. Joensuun yliopiston teologisia julkaisuja, 1. Joensuu: University of Joensuu.

Mustonen, Juuso 1931. Inkerin suomalaiset seurakunnat. Suomalaisen Kirjallisuuden Seuran toimituksia, 191. Helsinki: Suomalaisen Kirjallisuuden Seura.

Nenola, Aili 2002. Inkerin itkuvirret. Ingrian Laments. Suomalaisen Kirjallisuuden Seuran toimituksia, 735. Helsinki: Suomalaisen Kirjallisuuden Seura.

Pentikäinen, Juha 1968. The Nordic Dead-Child Tradition. The Nordic Dead-Child Beings: A Study in Comparative Religion. Folklore Fellows Communications, 202. Helsinki: Academia Scientarum Fennica.

Pozsony, Ferenc 2002. Hussitismus and Protestantismus in Moldavien. An international Festschrift to commemorate the 60th birthday of Mihály 
Hoppál. E. Bartha \& V. Anttonen (Eds.). Ethnogarphica et Folkloristica Carpathica, 12.-13. Debrecen-Turku: University of Debrecen, pp. 203215.

Raudalainen, Taisto 2003. "A vot, ne unet on ku petsatil' painettui aivoloihe." Inkerinsuomalaisen uni- ja ilmestyskerronnan yhteyksistä ortoksisperäiseen obmiranie-perinteeseen. Elore, 2. http://www.cc. joensuu.fi/ loristi/2_03/rau203.html.

Raudalainen, Taisto. 2004. The Religious Practice of Mirskoye Obmiraniye: The Motifs of Old Slavonic Apocrypha Reflected in Ingrian Folk Narratives. Pro Ethnologia, 17. Perceptions of Worldviews. T. Anepaio \& P. Runnel (Eds.). Tartu: Eesti Rahva Muuseum, pp. 149-174.

Raudalainen, Taisto et al. 2004. “...ja päästa meid ära kurjast!” [TVprogramme.] Tallinn: Eesti Televisioon, TV \& E-Meedia.

Saarinen, Risto 1989. Luterilainen kuolema ennen ja nyt: Synty ja kuolema. Lopun ajat eilen ja tänään. R. Saarinen \& R. Uro (Eds.). Tampere: Kirkon tutkimuskeskus.

Sahlins, Marshall David 2000. Culture in Practice: Selected Essays. New York: Zone Books.

Saloheimo, Veijo 1991. Inkerinmaan asutus ja väesto 1618-1700. Inkeri: historia, kansa, kulttuuri. H. Sihvo \& P. Nevalainen (Eds.). Suomalaisen Kirjallisuuden Seuran toimituksia, 547. Helsinki: Suomalaisen Kirjallisuuden Seura, pp. 67-81.

Sihvo, Hannes 1991. Inkeriläisten identiteetti muutosten paineissa. Inkeri: historia, kansa, kulttuuri. H. Sihvo \& P. Nevalainen (Eds.). Suomalaisen Kirjallisuuden Seuran toimituksia, 547. Helsinki: Suomalaisen Kirjallisuuden Seura, pp. 343-355.

Sihvo, Hannes \& Nevalainen, Pekka (Eds.) 1991. Inkeri: historia, kansa, kulttuuri. Suomalaisen Kirjallisuuden Seuran toimituksia, 547. Helsinki: Suomalaisen Kirjallisuuden Seura.

Siikala, Anna-Leena 2000. From Sacrificial Rituals into Native Festivals: Post-Soviet Transformations of Udmurt Tradition. Folklore, Heritage Politics and Ethnic Diversity: a Festschrift for Barbro Klein. P. J. Anttonen \& A.-L. Siikala \& S. R. Mathisen \& L. Magnusson (Eds.). Botkyrka: Multicultural Centre, pp. 57-85.

Torp-Kõivupuu, Marju 2003. Surmakultuuri muutumine ajas: ajaloolise Võrumaa matusekombestiku näitel. Tallinna Pedagoogikaülikooli toimetised. A, Humaniora, 22. Tallinn: Tallinna Pedagoogikaülikooli kirjastus.

Vilkuna, Asko 1989. Tavan takaa: Kansatieteellisiä tutkimuksia tapojemme historiasta. Jyväskylän yliopiston etnologian laitoksen tutkimuksia, 24. Jyväskylä: Jyväskylän yliopisto.

Vilkuna, Janne 1992. Suomalaiset vainajien karsikot ja ristipuut. Kansatieteellinen tapatutkimus. Kansatieteellinen Arkisto, 39. Jyväskylä: Gummerus Kirjapaino Oy.

Väänänen, Kyösti 1987. Herdaminne för Ingermanland. I. Lutherska Stiftsstyrelsen, församlingarnas prästerskap och skollärare i Ingermanland 
under svenska tiden. Skrifter utgivna av Svenska Litteratursällskapet i Finland, 538. Helsingfors: Svenska Litteratursällskapet i Finland. 